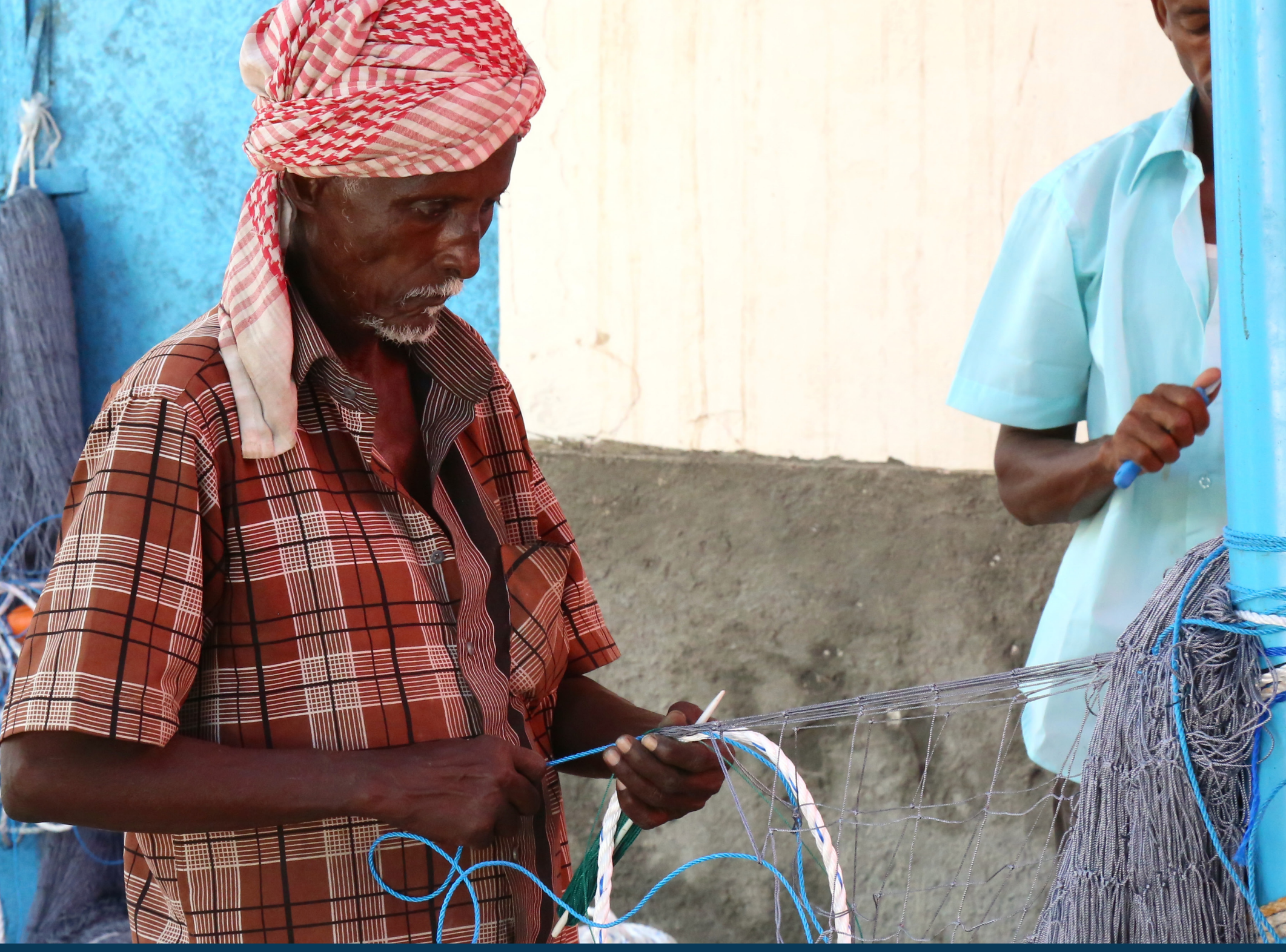

\title{
An Exploration of
}

\section{FEDERAL FISHERIES MANAGEMENT AGENCIES}

\section{in Eastern Africa}

February | 2017

Paige M. Roberts

Laura C. Burroughs

Robert H. Mazurek

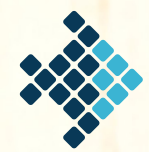

SECURE FISHERIES 


\section{ACKNOWLEDGMENTS}

The authors would like to thank the reviewers of this document in Mozambique, Eritrea, Tanzania, Kenya, and the Seychelles. Their input greatly contributed to the accuracy of each section. We appreciate the editing help provided by Sarah Glaser, Kaija Hurlburt, and Lindsay Heger. Thanks also to Andrea Kuenker and Timothy Schommer for the report's layout and design.

For all figures included in this document, only the agencies discussed have been represented.

Secure Fisheries is a program of the One Earth Future Foundation

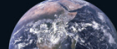

2.

one earth

F U T U R E

Peace Through Governance

oneearthfuture.org

http://dx.doi.org/10.18289/OEF.2017.014

(c) 2017 One Earth Future Foundation 


\section{TABLE OF CONTENTS}

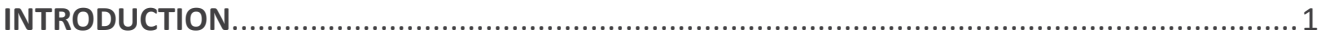

REGIONAL EXAMPLES OF FISHERIES MANAGEMENT AGENCIES .......................................2

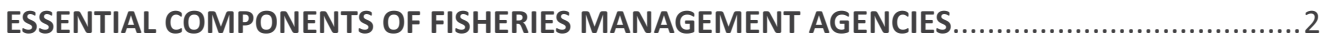

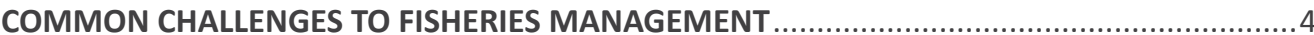

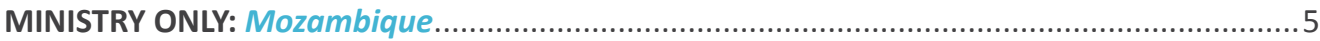

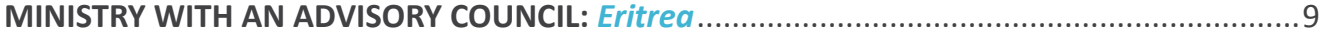

FISHING AUTHORITY UNDER THE MINISTRY: Tanzania ................................................ 13

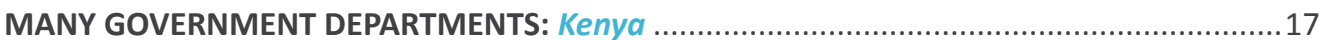

SEMI-AUTONOMOUS FISHING AUTHORITY: Seychelles................................................23

APPENDICES

securefisheries.org/illegal-fishing-resources.org

APPENDIX 1A: Full text of the Decreto Pesidencial n. ${ }^{\circ}$ 17/2015 from Mozambique. Published March 25, 2015, in the Boletim da República, I Série, Supplement, No. 24. (in Portuguese)

APPENDIX 1B: Full text of the Lei n. 22/2013 from Mozambique. Published November 1, 2013 in Boletim da República No. 88. (in Portuguese)

APPENDIX 2. Full text of the Fisheries Proclamation (No. 104/1998) from Eritrea. Published May 25, 1998, in the Gazette of Eritrean Laws, Vol. 8, No. 4.

APPENDIX 3. Full text of The Deep Sea Fishing Authority Act (Cap. No. 388) from Tanzania. Published March 6, March 2009 in Government Notice No. 48.

APPENDIX 4A. Full text of Executive Order No. 1: Structure of the National Executive of 2013. Published April 18, 2013 in The Kenya Gazette, Vol. CXV-No. 61.

APPENDIX 4B. Full text of the Fisheries Act (Cap. 378) from Kenya. Published December 31, 2012 in Laws of Kenya.

APPENDIX 4C. Fisheries Management and Development Act No. 35 of 2016

APPENDIX 5A. Full text of the Seychelles Fishing Authority (Establishment) Act, consolidated to 30 June 2014. Published in the Official Gazette.

APPENDIX 5B. Full text of the Fisheries Act, 2014 from the Seychelles. Published October 27, 2014 in the Supplement to Official Gazette. 


\section{INTRODUCTION}

For coastal countries in the Western Indian Ocean region, fisheries are a vital component of their economies and local livelihoods. Ensuring fisheries sustainability requires strong national-level governance through legislation and a management agency. Fisheries management agencies in the region use a variety of organizational structures, but all have common mandates to create regulations on fisheries and enforce those regulations. This document outlines the structure and functions of fisheries management agencies from five countries in the region: Mozambique, Eritrea, Tanzania, Kenya, and the Seychelles. It focuses primarily on federal-level management of commercial fishing and offshore resources. Local artisanal fishing in these countries is managed separately, often at the district or community level, so this document only briefly touches on those systems.

This document is not comprehensive. Rather, it identifies the most important elements of fisheries management agencies and shows examples of ways to incorporate those into a national agency structure. Exploring the similarities and differences among these countries' systems highlights the ways they have created agencies to suit their individual needs. By showcasing different models in one document, other countries and the international community currently developing fisheries management agencies may be able to incorporate some of the strategies covered here, while also understanding the potential difficulties.

It is relevant to note that although these countries have a thorough legal outline of their fisheries management systems, they may currently lack the capacity or political will to fully implement those systems. Some of the management agencies were created very recently, so in some cases people to fill each outlined position have yet to be identified and appointed. Additionally, full implementation often takes time and financial resources. While the guiding documents are forward-thinking and aspirational, some of the management protocols are not currently being followed in practice. Thus, the descriptions here are general and largely based on the laws and the vision each country has for its ideal fisheries management structure. 


\section{REGIONAL EXAMPLES OF FISHERIES MANAGEMENT AGENCIES}

Sustainable marine fisheries are crucial to coastal states' economic and food security. Maintaining sustainable fisheries and effectively using them to increase local and national revenue requires an agency with a stable and well-organized management structure, determined by strong fisheries legislation. There are many different models of fisheries management working to support fisheries and allow a sustainable level of catch. Each model has the same essential components, but the entity in charge, the power structure, and the connection to the central government varies by country.

In this document, we choose five example countries from eastern Africa and examine their fisheries management organizations and how they handle related duties. Our goal is to inform the governments of the Western Indian Ocean region and the international community about different structures in order to foster a better understanding of and cooperation among the agencies of these countries. We hope that by comparing different systems, previously unrealized benefits of an alternative system can be incorporated into another country's agency. No single system is perfect, and a country in the region may learn something from another system that will strengthen its ability to fairly and efficiently manage its fisheries. The countries we highlight are:
1) Mozambique, which manages everything through a single government agency;
2) Eritrea, which similarly manages its fisheries through a single government agency, but has an additional advisory panel of stakeholders outside the agency;
3) Tanzania, which uses a geographic distinction to allow a branch of the overarching government agency to manage off-shore fisheries separately from inland and coastal fisheries;
4) Kenya, which distributes management duties across multiple government organizations; and
5) Seychelles, which has a semi-autonomous fishing authority under a government agency.

\section{ESSENTIAL COMPONENTS OF FISHERIES MANAGEMENT AGENCIES}

In eastern Africa, many countries have created agencies under the federal government to manage their fisheries and enforce fisheries laws and regulations. Though each country has a unique design based on its specific needs, there are common functions of all federal fisheries management agencies that are essential for effective management. These functions are:

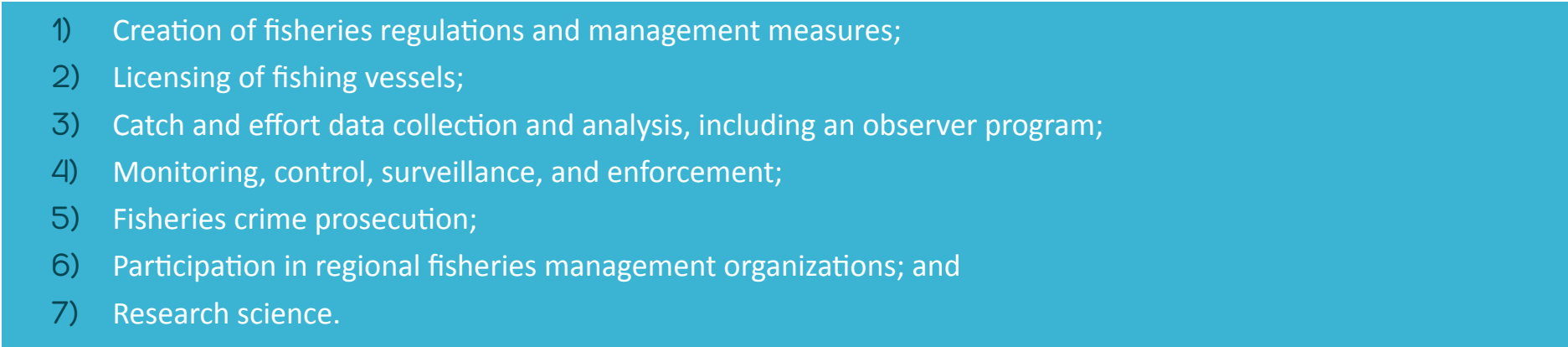

Fisheries management agencies must fulfil numerous responsibilities. The foremost duty of any fisheries management agency is the creation and implementation of regulations and adaptive management measures with the goal of longterm sustainability of fish stocks and associated marine habitats. The most successful management measures balance the needs of fishers with the ability of fish stocks and the environment to support those needs. The fisheries management agency must also consider the economic and food security needs of local fishers and other stakeholders, the capacity of the fisheries to sustain increased pressure from foreign fishers, and the data collection and scientific analyses of fish stocks and important habitats. Finally, the management entity must be responsive to new information on marine resources and 
changes in regional fisheries management measures. It therefore requires the flexibility to modify regulations in response to new information.

The most direct means of ensuring long-term sustainability of fisheries is by managing the amount of fish removed from a country's waters, including catch limits and gear restrictions. To control catch levels, management agencies utilize strict fishing vessel licensing requirements, especially of foreign vessels. In most places, an assessment of the total amount of fisheries resources available is completed and the amount of fish that can be sustainably removed is determined. This provides an estimate of the ideal total allowable catch (often referred to as TAC), and informs a baseline from which allocation to domestic fishers should first be made. The level of domestic, small-scale fishing is often managed at a provincial or district level, with oversight by the national management agency.

The remainder of the allowable catch is then either available for removal by foreign vessels that receive licenses from the fisheries management agency or preserved to act as a buffer in case of the mismanagement of these resources. In a successful licensing regime, the list of licensed vessels is made publicly available through accessible outlets such as newspapers or the authority's website. This is critical for stopping illegal fishing because the public listing allows anyone who encounters a boat on the water or in port to determine the vessel's legal status. Licenses are issued for a fee, and license revenue is typically used to support the functions of the fisheries management agency with surplus used to invest in fishing infrastructure or associated projects.

The next step in managing fishing in a country's waters requires documentation of the amount of fish caught. All vessels fishing in the exclusive economic zone (EEZ) of a country are required to report their catch to the fisheries management agency. There are different reporting methods available, ranging from written logbooks to automated electronic reporting. All data, including the amount (total weight), species composition, and location of catch, are reported to the management agency. These data are then analyzed and used to determine if the level of fishing is appropriate and sustainable for that area and species.

Confirmation of the accuracy of these catch reports is done by on-board observers. These are professionals trained by the management agency who work on fishing vessels and collect biological data about the catch. Observers are required on a specified proportion of licensed vessels fishing for highly migratory species. This proportion is determined by regional fisheries management organizations (RFMOs), such as the Indian Ocean Tuna Commission (IOTC).

Beyond vessel licensing and documenting catch amounts, a fisheries management agency must: 1) have the capacity to fight illegal, unregulated, and unreported (IUU) fishing; 2) be responsible for monitoring, control, and surveillance (MCS) of their EEZ; and 3) enforce national and international fishing laws. Ideally, this involves technologically advanced equipment such as vessel monitoring systems (VMS) to track any vessel fishing in the EEZ.

There is substantial MCS coordination among Western Indian Ocean countries. The countries with the highest MCS capacities, such as Mozambique, monitor their own waters and those of nearby countries that lack the advanced technology necessary to track vessels. Enforcement includes patrols on the water by authorized officers that have powers to board and inspect vessels suspected of IUU fishing. Enforcement also extends into ports where similar inspections occur.

If evidence of a fisheries crime is found, many fisheries management agencies have a department to handle prosecutions. At a minimum, the fisheries management agency is able to levy fines and revoke licenses of suspect vessels. Some countries will take additional steps and prosecute these crimes in court and/or confiscate fishing vessels. Some of these confiscated vessels have even been repurposed as patrol boats.

Furthermore, it is the duty of the fisheries management agency to participate in relevant RFMOs. These may be based on geography (i.e., the South West Indian Ocean Fisheries Project) or on species management (i.e., the IOTC). The officials of the fisheries management agency should participate in meetings of these RFMOs as they can represent the best interests of their country's fisheries sector and have the power to incorporate regional mandates into their country's regulations. 
A research science branch is the final key component of a fisheries management agency. Although in some cases they are a separate entity from the fisheries management agency itself, research science and analysis must form the basis of fisheries policies. The science program can hold the catch data records and perform assessments of sustainable catch levels. Science departments also perform surveys and experiments that inform fisheries policies, such as the establishment of total allowable catch and marine protected areas.

\section{COMMON CHALLENGES FOR FISHERIES MANAGEMENT}

Each of the countries we discuss shares the same challenges for fisheries management that are pervasive in the region. These include:

- Each country has a constituency of small-scale fishers whose interests must be prioritized.

- The fisheries management agency of each country must determine the level of domestic and foreign fishing based on the needs of their economy and environmental sustainability.

- The waters of each country support valuable populations of highly migratory species such as tuna, billfish, and mackerel that pass through their EEZs, forcing them to coordinate regionally through RFMOs to manage those stocks and the fishing pressure on them.

- Most countries in this region are waging a battle against IUU fishing and are building their capacity to monitor their EEZs. Fisheries management agencies are therefore tasked with creating a transparent system of licensing foreign vessels that does not disadvantage local fishers.

- Each example country has recently reviewed and adapted its fishing laws to consider regional and international interests and incorporate new fisheries science and MCS technology.

Overall, maintaining sustainable fisheries is crucial to the future food and economic security of every country bordering the Western Indian Ocean. 


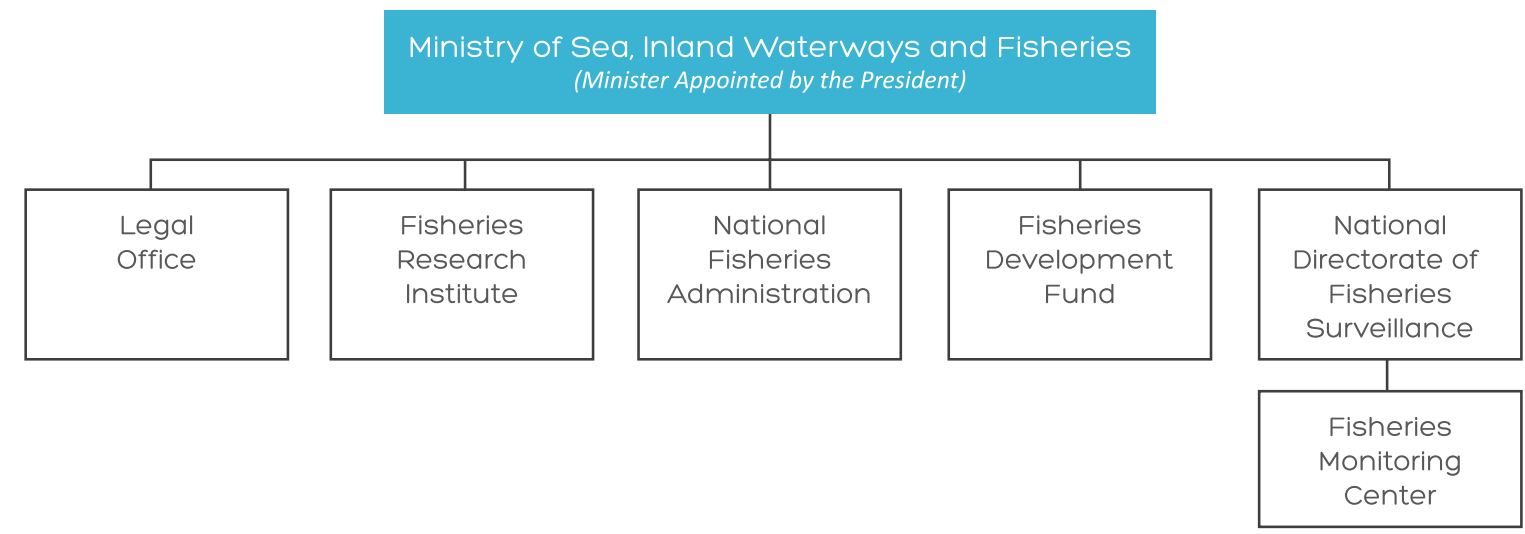

The most centralized system for fisheries management by the government is exclusively through one body, such as a ministry. In Mozambique, the Ministry of Sea, Inland Waterways and Fisheries was established by a presidential decree, ${ }^{1}$ a document that can be amended by future presidential decrees (the last revision was in $2015 ;^{2}$ see Appendix 1 for the full text). The Ministry is funded through a combination of external donor support, federally appropriated $m$ oney, and license fees, which go toward ministerial functions and fishery development programs. ${ }^{3}$

Ministerial duties are outlined in another presidential decree ${ }^{4}$ and in the current fisheries law, Fisheries Law no. 22/2013 which was passed by Parliament. Under this system, the Minister is appointed by the President, and all final decisions go through him or her. The Minister appoints directors and oversees the departments and directorates that handle all matters of fisheries management. The departments and directorates are separated into two sections: the legal and policymaking branch, and the implementation branch. ${ }^{6}$ Much of local implementation is carried out by Provincial Directorates. This ensures decisions and projects serve to benefit the economic and food security of the people of Mozambique, an important overarching goal of the Ministry. ${ }^{7}$

\section{Creation of Fisheries Regulations and Management Measures}

According to Mozambican law, regulations and plans for fisheries and aquaculture use the best scientific information available to adhere to principles of 1) conservation of aquatic species and habitats, 2) sustainability, 3) food safety, and 4) reduced poverty. The regulations are drafted by the Department of Law with the input of scientists. They are then accepted or rejected by the Ministry. ${ }^{8}$

Regulations on catch are drafted in consultation with the scientists at the Fisheries Research Institute (Instituto Nacional de Investigação Pesqueira), which is a department of the Ministry. ${ }^{9}$ Regulations and procedures on licensing, monitoring of fishing vessels, observers, and enforcement official authorizations are created when necessary by the departments or directorates responsible for each activity.

\section{Licensing}

In Mozambique, the territorial sea up to three nautical miles is reserved for subsistence and small-scale fishing, scientific research, and recreational and sport fishing. ${ }^{10}$

All fishing vessels must be registered and pay a fee, as determined by the government, except those associated with subsistence fishing. ${ }^{11}$ 
Small-scale fishing is governed using a co-management format in which local fishing communities form fishing associations to manage their resources at the local level, in cooperation with provincial government officials. ${ }^{12}$

Industrial fishing vessels may operate within the EEZ but outside of the three nautical mile boundary reserved for smallscale fishing. National and foreign owners of industrial vessels obtain licenses from the National Fisheries Administration (Administração Nacional das Pescas), which is responsible for regulatory controls. Requirements to obtain a license are outlined in the Fisheries Law and vary based on the resource a vessel is exploiting. Access fees are reduced for vessels that agree to land their catch in Mozambique..$^{13}$

Fees from licenses are transferred to the Fisheries Development Fund (Fundo de Fomento Pesqueiro), which manages and distributes funds among ministerial departments. A portion of these resources is then directed toward investment in public, private, or research projects. ${ }^{14}$ The Fisheries Development Fund is the main financial body of the Ministry and is also responsible for distributing income from private or international aid agency donations. ${ }^{15}$

The National Fisheries Administration makes license information available by request. Additionally, as a member of the IOTC, Mozambique provides a list of vessels authorized to fish for highly migratory species, which the IOTC publishes on its website. ${ }^{16}$

Catch and Effort Data Collection and Analysis, Observer Program

The Ministry has been collecting catch and effort data from industrial vessels fishing in Mozambican waters since the early 1980s. The Fisheries Research Institute (Instituto Nacional de Investigação Pesqueira) collects and analyzes catch data from vessel master logbooks via an Electronic Reporting System (ERS). ${ }^{17}$ The data are entered into an ERS system on board the vessel and immediately transmitted to the Fisheries Monitoring Center, then to the Research Institute. ${ }^{18}$ Analyses and recommendations by the Fisheries Research Institute inform the regulations put forth by the Minister.

The Ministry supplements the logbook data with data from observers on board industrial vessels. Data from artisanal fishing operations are gathered at the provincial level and used to locally manage those fisheries. ${ }^{19}$

\section{Monitoring, Control, Surveillance, Enforcement}

MCS is handled by the Fishery Monitoring Center, a branch of the National Directorate of Fisheries Surveillance (Direcção Nacional da Fiscalização das Pescas).

The fishery law mandates all national and foreign industrial fishing vessels must be equipped with a Vessel Monitoring System (VMS) to track their fishing activities within the EEZ (and on the high seas for Mozambique-flagged vessels). ${ }^{20,}, 21$ Mozambique has developed its capacity for electronic monitoring of vessels substantially over the past few years, and it is a regional MCS hub for the waters of the South Africa Development Community (SADC). ${ }^{22}$ The National Directorate of Fisheries Surveillance works closely with South Africa and Tanzania to monitor the Mozambique Channel to ensure the safety and legality of transiting and working vessels. ${ }^{23}$

The Ministry is similarly responsible for at-sea patrols and is actively working to expand its fleet. In 2015, it acquired 30 patrol ships to supplement its previous two. ${ }^{24}, 25$ This greatly improved the Ministry's capacity to control fishing in Mozambican waters and pursue vessels suspected of illicit activities. The ministry, in partnership with the European Union, created programs to train the control officers in proper practices of boarding, inspections, and electronic surveillance. ${ }^{26}$

The fisheries law further establishes the duties of enforcement officials who have a wide range of authorizations. They enforce both national and international laws and are allowed to inspect vessels at sea or in port. Vessels are subject to inspection if they are suspected of 1) having improper documentation, 2) carrying illegal or unreported catches on board, 3) using unauthorized gear, or 4) maintaining unsanitary conditions making the seafood on board unfit for human consumption. ${ }^{27}$ The officials are authorized to seize any offending vessels, gear, or catch. ${ }^{28}$ These confiscations can be used as evidence to levy fines against the people responsible including captains, vessel owners, or fishing rights holders. ${ }^{29}$ 
Fisheries Crime Prosecution

Under the Ministry there is a Legal Office to handle prosecutions of fisheries crimes. The Minister has administrative rights and is able to impose sanctions and fines on vessels shown to be fishing illegally by the National Directorate of Fisheries Surveillance. ${ }^{30}$

Regional Fishery Management Organization Participation

The Ministry acts on behalf of the country of Mozambique in many regional fisheries management organizations. These include the Indian Ocean Tuna Commission (IOTC) ${ }^{31}$ and the South African Development Community (SADC). They were previously involved in the South West Indian Ocean Fisheries Project (SWIOFP) and the Agulhas and Somali Current Large Marine Ecosystem (ASCLME) before these projects ended..$^{32}$ As part of these organizations, Mozambique is helping the region to sustainably manage its highly migratory species stocks, maintain a healthy ecosystem to support fishing (artisanal and industrial), and is able to share data and MCS information with other countries that are part of these extensive networks.

\section{Research Science}

The Fisheries Research Institute conducts fishery-independent surveys of marine resources, focusing on the most economically valuable fish and invertebrate species. Species studied include many types of tuna, scad, mackerel, shrimp, small pelagic fishes, and spiny lobsters. Separate studies on artisanal fisheries have also been conducted..$^{3{ }^{3}}$

Scientists at the Fisheries Research Institute use these data in combination with fishery-dependent catch and effort data to help determine sustainable catch levels and create regulations to be passed by the Minister.

\section{Considerations and Implications for This System}

There are benefits in the simplicity of a ministry-led system. The organizational structure is logical and simple. With only one governing body, it is obvious where citizens and outside organizations should take issues related to fisheries. Additionally, it is clear who controls licensing and revenues, and therefore it is the purview of only one institution to decide how to use them, rather than complicating the flow of money among multiple institutions.

In Mozambique, the language included in its laws and regulations indicate the Ministry prioritizes the food and economic security of its people whose survival depends on fishing. The government leaves many decisions up to the coastal populations through their system of co-management in which the provincial governments and fishing communities cooperatively manage the resources. This likely empowers citizens and increases the likelihood that the decisions will benefit them and their communities.

However, there are five potential drawbacks to this system:

1. There is no official mechanism outlined in the law for the inclusion of all stakeholders in creating management plans and advising the Ministry. The Minister's expertise alone may not reach into every area that needs to be managed, so the formal inclusion of additional stakeholders would diversify the experience and knowledge of the decision maker. In many other countries (i.e. Eritrea and Kenya), an official fisheries advisory council is in place to guide decisions to be made by the Ministry.

2. Without an advisory council, this system lacks a formal oversight mechanism to which the Ministry is held accountable.

3. Concentration of decision-making power at the ministerial level risks emphasis on those fisheries that have the largest economic impact nationally, often at the expense of smaller, less valuable fisheries that are nonetheless important sources of food security and ecosystem sustainability.

4. Concentrating final decision-making and approvals in the authority of one Minister can create a bottleneck leading to slower decision-making.

5. Subordinate institutions may face reduced autonomy and an inability to act separately from the Ministry when their needs diverge. 


\section{Notes (Mozambique)}

1. Decreto Pesidencial n. ${ }^{\circ}$ 1/2000 de 17 Janeiro. Boletim da República, I Serie. Retrieved from http://faolex.fao.org/cgi-bin/faolex.exe?rec id=047073\&database=faolex\&search type=link\&table=result\&lang=eng\&format name=@ERALL

2. Decreto Pesidencial n. ${ }^{\circ}$ /2015 de 16 de Janeiro. Boletim da República, / Série, No. 5. Retrieved from http://faolex.fao.org/cgi-bin/faolex.exe?rec id=148451\&database=faolex\&search type=link\&table=result\&lang=eng\&format name=@ERALL

3. Oceanic Développement, MegaPesca Lda. (2014). Ex-post and ex-ante evaluations of the protocol to the Fisheries Partnership Agreement between the EU and the Republic of Mozambique. Retrieved from http://ec.europa.eu/fisheries/documentation/studies/mozambique/

4. Decreto Pesidencial n. ${ }^{\circ}$ 17/2015 de 25 de Março. Boletim da República, I Série, Supplement, No. 24. Retrieved from http://faolex.fao.org/cgi-bin/ faolex.exe?rec id=148448\&database=faolex\&search type=link\&table=result\&lang=eng\&format name=@ERALL

5. Lei n. 22/2013 de 1 de Novembro de 2013. Boletim da República No. 88. Retrieved from http://faolex.fao.org/cgi-bin/faolex.exe?rec

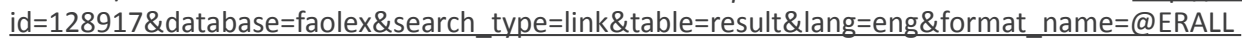

6. Oceanic Développement, MegaPesca Lda., Ex-post and ex-ante evaluations

7. Kabubu, J. (23 April 2013). New Fisheries Act Lays Basis for Sustainable Fisheries in Mozambique. Retrieved from http://wwf.panda.org/?208342/ New-Fisheries-Act-Lays-Basis-For-Sustainable-Fisheries-In-Mozambique

8. Decreto Pesidencial n. ${ }^{\circ} 1 / 2015$, Title 1 , Article 5

9. Decreto Pesidencial n. ${ }^{\circ} 1 / 2015$, Section VI, Article 51

10. Decreto Pesidencial n. ${ }^{\circ} 1 / 2015$, Section III, Article 27

11. Decreto Pesidencial n. ${ }^{\circ} 1 / 2015$ Section III, Article 30, Article 35

12. Stop Illegal Fishing. Country Profile: Mozambique. Retrieved from http://www.stopillegalfishing.com/doc/publication/eng/mozambique country profile.pdf

13. Oceanic Développement, MegaPesca Lda. (2011). Ex-post evaluation of the current protocol to the fisheries partnership agreement between the European Union and Mozambique and analysis of the impact of the future protocol on sustainability, including ex-ante evaluation. Retrieved from http://transparentsea.co/images/0/09/EC evaluation Mozambique2011.pdf

14. Oceanic Développement, MegaPesca Lda., Ex-post and ex-ante evaluations

15. Ibid.

16. Government of Mozambique. (26 February 2015). Report of Implementation for the year 2014. IOTC-2015-CoC12-IR19[E]. Retrieved from http:// www.iotc.org/documents/compliance-report-mozambique-0

17. Doherty, B., McBride, M.M., Brito, AJ., Le Manach, F., Sousa, L., Chauca, I. and Zeller, D. (2015.) Marine fisheries in Mozambique: catches updated to 2010 and taxonomic disaggregation. Pp. 67-81 In Le Manach, F. and Pauly, D. (eds.) Fisheries catch reconstructions in the Western Indian Ocean, 1950-2010. Fisheries Centre Research Reports 23(2). Fisheries Centre, University of British Columbia [ISSN 1198-6727]. Retrieved from http://www.seaaroundus.org/doc/publications/chapters/2015/Doherty-et-al-Mozambique.pdf

18. Oceanic Développement, MegaPesca Lda., Ex-post and ex-ante evaluations

19. Doherty et al., Marine fisheries

20. Decreto Pesidencial n. ${ }^{\circ} 1 / 2015$, Section 6, Article 54

21. Oceanic Développement, MegaPesca Lda., Ex-post and ex-ante evaluations

22. Ibid.

23. Walker, T. 2015, September 15. It's time to ride the blue economy. Business Day. Retrieved from http://www.bdlive.co.za/opinion/2015/09/15/ its-time-to-ride-the-blue-economy

24. Ibid.

25. Oceanic Développement, MegaPesca Lda., Ex-post and ex-ante evaluations

26. Ibid.

27. Decreto Pesidencial n. ${ }^{\circ} 1 / 2015$, Title III, Chapter I, Article 72

28. Decreto Pesidencial n. ${ }^{\circ} 1 / 2015$, Title III, Chapter I, Article 76

29. Decreto Pesidencial n. ${ }^{\circ} 1 / 2015$, Title III, Chapter I, Article 87

30. Stop Illegal Fishing. The Spanish flagged vessel Txori Argi has been charged for illegal fishing in Mozambique EEZ. Retrieved from http://www. stopillegalfishing.com/sifnews article.php?ID=83

31. Indian Ocean Tuna Commission. Structure of the Commission. Retrieved from http://www.iotc.org/about-iotc/structure-commission

32. Oceanic Développement, MegaPesca Lda., Ex-post and ex-ante evaluations

33. Bandeira, S.O., Silva, R.P., Paula, J., Macia, A., Hernroth, L., Guissaulo, A.T., Gove, D.Z. (2002). Marine Biological Research in Mozambique: Past, Present and Future. A Journal of the Human Environment, 31(7):606-609. doi: 10.1579/0044-7447-31.7.606 
MINISTRY WITH AN ADVISORY COUNCIL: ERITREA

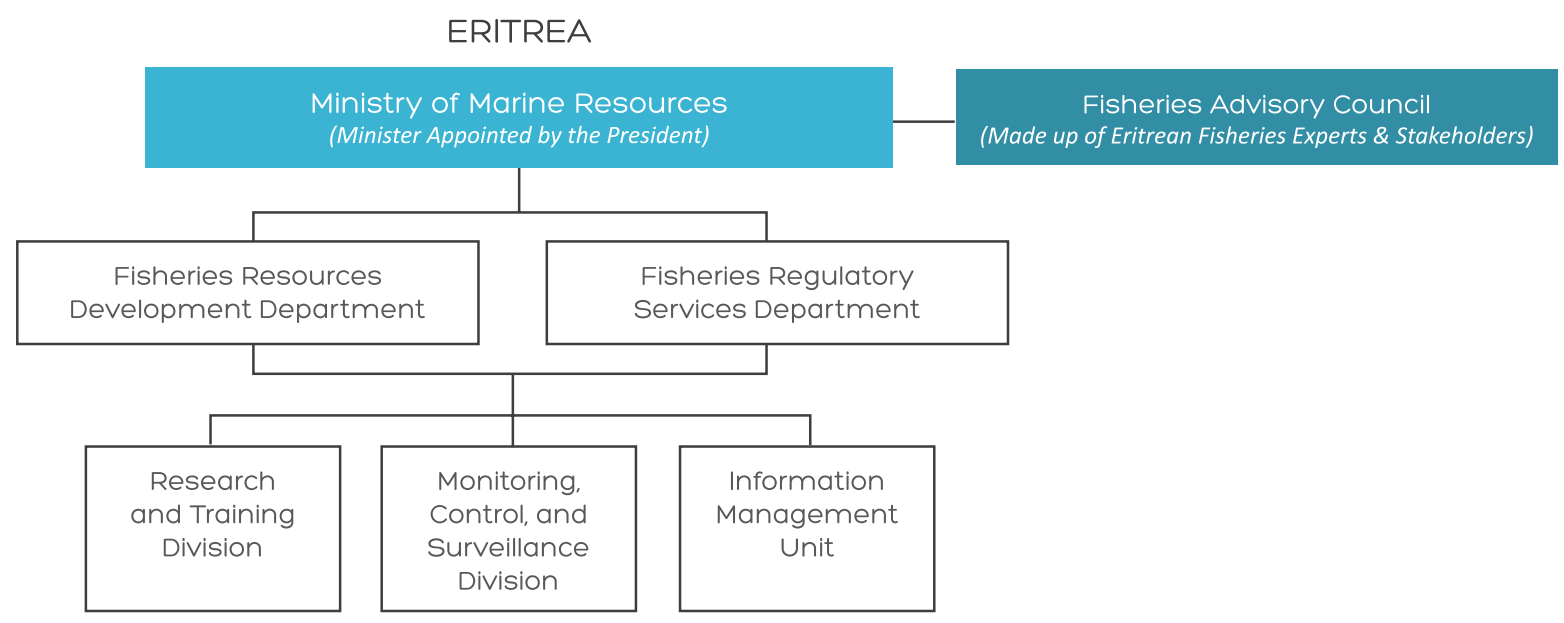

Eritrea manages its fisheries under the Ministry of Marine Resources, but with the addition of stakeholder advisors. Though it has been called many different names, the government agency in charge of fishing related matters is the Ministry of Marine Resources. It was established in 1991 by Fisheries Proclamation No. 104/1998 (see Appendix 2 for the full proclamation text), which has since been repealed by the Fisheries Proclamation No. 104/2014 (full text unavailable). The Ministry of Marine Resources has complete jurisdiction over Eritrea's marine and aquatic resources. Eritrea also established the Fisheries Advisory Council (FAC) to help guide decisions of the Ministry and more broadly represent the interests of various stakeholders in the fisheries sector.

The FAC consists of government and industry representatives ${ }^{2}$ including:

1) An officer of the Ministry to ensure the Proclamation is adhered to;

2) A representative of the department responsible for ports and maritime transport;

3) A Navy representative;

4) A representative of the department responsible for economic development and investment;

5) A representative of the Research and Training Division of the Ministry;

6) An elected representative of the artisanal fishing community;

7) An elected representative for operators of foreign fishing vessels;

8) An elected representative of Eritrean commercial fishing vessels when applicable.

While the FAC is under the authority of the Ministry, it has a mandate to operate outside the Ministry and evaluate policies. The FAC conducts meetings, establishes internal procedures, and elects a chairperson. It can also involve relevant individuals from outside the Ministry and FAC to assist in decision-making.

Eritrea's Ministry is similar to that of Mozambique in that it has sole control over Eritrea's marine management and contains departments under it, the Fisheries Development Department and the Fisheries Regulatory Services Department, to fulfill its duties. ${ }^{4}$ For the purposes of this document, we focus on the added role of the FAC.

\section{Creation of Fisheries Regulations and Management Measures}

The primary function of the FAC is to advise the Ministry on fisheries management and development plans that prioritize conservation and sustainability. The Ministry outlines a management plan and licensing program using resource assessments conducted by the Research and Training Division of the Ministry. The FAC provides input on the drafted management plan. ${ }^{5}$ 
The Fisheries Proclamation established various conservation measures including 1) protected areas and species, ${ }^{6}$ 2) limitations on gear and fishing practices, ${ }^{7}$ and 3 ) closed seasons. ${ }^{8}$ Eritrea enforces limitations on fishing practices and species exploitation, such as trawling, spear fishing, and the export of live corals. ${ }^{9}$

Eritrea is developing marine protected areas..$^{10}$ The Minister consults with the FAC in the establishment of protected areas in addition to owners and residents of adjoining land, appropriate local government councils, and the authorities responsible for other uses of the area. ${ }^{11}$

\section{Licensing}

A licensing program is central to the management of Eritrea's marine resources. The Ministry uses a licensing program that limits the number of licenses given to national and foreign vessels. The FAC provides guidance on the management plan, which includes the licensing program. ${ }^{12}$ Artisanal fishers operate under open access licensing. ${ }^{13}$

The FAC does not have jurisdiction over licensing agreements outside of fisheries management and development plans. ${ }^{14}$

\section{Catch and Effort Data Collection and Analysis, Observer Program}

The Fisheries MCS Division of Eritrea also collects catch and effort data through their Inspectors. They relay data to the Information Management Unit of the Ministry of Fisheries where it is stored and analyzed for distribution to the public and policy makers. ${ }^{15}$ The FAC is not involved in these activities.

The Ministry also has an observer program, but the FAC is not involved in it. ${ }^{16}$

\section{Monitoring, Control, Surveillance, Enforcement}

Following the creation of the Ministry of Fisheries, Eritrea established the Fisheries Monitoring, Control, and Surveillance (MCS) Division of Eritrea. It covers both artisanal and industrial fisheries. It was originally composed of former military personnel, but was slowly populated by trained recruits from the Hirgigo Training Center ${ }^{17}$ and students from the College of Marine Sciences and Technology. ${ }^{18}$ The MCS Division includes a group of trained inspectors who gather onboard information including fish caught, gear, and fishing operations, and assess that vessel equipment is up to standard. ${ }^{19}$ Two or three inspectors are required on board any industrial fishing vessel.

The Minister also appoints a group of Authorized Officers ${ }^{20}$ who are tasked with enforcement. They are entitled to stop and board fishing vessels without warrant. They also have power of search and seizure for vessels, gear, and other relevant items. Eritrea's enforcement system is similar to that of Mozambique. The FAC is not involved in MCS or enforcement. ${ }^{21}$

\section{Fisheries Crime Prosecution}

Fisheries crime prosecution is a high priority of the Ministry. The 1998 legislation outlines various offenses ${ }^{22}$ and resulting penalties. ${ }^{23}$ There are a wide variety of offenses, from improper stowage of fishing gear to fishing protected species. Penalties depend on the severity of the offense, ranging from fines ${ }^{24}$ to forfeiture of vessels ${ }^{25}$ or licenses. ${ }^{26}$ The legislation $^{2}$ also instructs fisheries crime prosecution by delineating admissible evidence ${ }^{27}$ and burden of proof. ${ }^{28}$

\section{Regional Fishery Management Organization Participation}

Eritrea is a member (Contracting Party) of the Indian Ocean Tuna Commission (IOTC). ${ }^{29}$ 


\section{Research Science}

Marine research is conducted through the Research and Training Division (RTD) of the Ministry. The RTD collects data on the marine ecosystem and fish stocks. It also promotes sustainability through environmental awareness campaigns and training programs. Training programs teach fishers a variety of skills and train women on nutrition. ${ }^{30}$ The Minister must authorize all fisheries research within Eritrean waters. ${ }^{31}$ While there is a representative of the RTD of the Ministry in the FAC, the FAC does not perform or consult on research.

\section{Considerations and Implications for This System}

The Eritrean system of the Fisheries Advisory Council to support Ministry decisions has similar benefits as a Ministry-only system, such as a simple power structure and income generation and redistribution (see Ministry Only: Mozambique). However, with the incorporation of the Fisheries Advisory Council, Eritrea resolves many of the concerns about a Ministryonly system. Because the Ministry must consult the FAC on fisheries management plans, it ensures the incorporation of different perspectives and interests, including those of artisanal fishers, who are often overlooked. Immediate access to these advisors also benefits the Ministry, as it decreases the burden of data collection. The FAC provides the Ministry with information and advice on all relevant fisheries issues, from economics to scientific research. Finally, the potential for Eritrean citizens' trust in the Ministry and respect for its policies is increased through stakeholder involvement in the FAC. Since the implementation of this management structure, strong adherence to fisheries management plans has been displayed in Eritrea. ${ }^{32}$

Incorporation of such a wide array of stakeholders may also have drawbacks. Each group represented in the FAC may have different, opposing interests in fisheries management plans. For example, a policy that benefits the commercial fishing industry could be harmful to artisanal fishers. This could create divides and risks stalemate within the advisory council. Also, reaching agreement and creating recommendations could take more time than in systems with a unilateral decision maker. 


\section{Notes (Eritrea)}

1. Fisheries Proclamation (No. 104/1998). (25 May 1998). Gazette of Eritrean Laws, Vol. 8, No. 4, pp. 1-17. Retrieved from http://www.eritreanlawsociety.org/els_pdf/Vol_//Fisheries\%20Proclamation\%20(No.\%20104_1998).pdf

2. Fisheries Proclamation, Part II, Art. 6

3. Ibid.

4. FAO Fisheries and Aquaculture Department. (2014). The State of Eritrea. Fishery and Aquaculture Country Profiles. Retrieved from http:// www.fao.org/fishery/facp/ERI/en

5. Fisheries Proclamation, Part III, Art. 7

6. Fisheries Proclamation, Part III, Art.13

7. Fisheries Proclamation, Part III, Art. 12

8. Fisheries Proclamation, Part III, Art. 9

9. The International Fund for Agricultural Development. (2010). The State of Eritrea Fisheries Development Project: Project Design Report. Retrieved from https://www.ifad.org/documents/10180/faaa06f9-4565-4115-ace9-a00f060a7d08

10. Global Environment Facility. (1996). Conservation Management of Eritrea's Coastal, Marine and Island Biodiversity. Retrieved from http:// www.thegef.org/gef/sites/thegef.org/files/gef pri docs/GEFProjectDocuments/Biodiversity/Eritrea\%20-\%20Conservation\%20management\%20of\%20Eritrea's\%20coastal\%20and\%20island\%20biodiversity/Project\%20document\%20for\%20WP.pdf

11. Fisheries Proclamation, Part III, Art. 13

12. Fisheries Proclamation, Part III, Art. 7

13. FAO, The State of Eritrea

14. Fisheries Proclamation, Part III, Art. 7

15. Ghebremariam, S. and Ghebretensae, Y. (2000). Fisheries Status in Eritrea: perspectives of fisheries MCS. Report of a Regional Workshop on Fisheries Monitoring, Control and Surveillance. Muscat, Oman, 24-28 October 1999.

16. FAO, The State of Eritrea

17. Marine Resources Ministry graduates members trained in different disciplines. (3 August 2013). Retrieved from http://www.shabait.com/ news/local-news/14286-marine-resources-ministry-graduates-members-trained-in-different-disciplines

18. The International Fund for Agricultural Development, The State of Eritrea Fisheries Development

19. Ghebremariam and Ghebretensae, Fisheries Status

20. Fisheries Proclamation, Part II, Art. 4

21. Fisheries Proclamation, Part VI, Art. 29

22. Fisheries Proclamation, Part VI, Art. 35

23. Fisheries Proclamation, Part VI, Art. 36

24. Fisheries Proclamation

25. Fisheries Proclamation, PartVI, Art. 37

26. Fisheries Proclamation, PartVI, Art. 38

27. Fisheries Proclamation, PartVI, Art. 42

28. Fisheries Proclamation, PartVI, Art. 44

29. Indian Ocean Tuna Commission. Structure of the Commission. Retrieved from http://www.iotc.org/about-iotc/structure-commission

30. ICARDA, FAO, AARINENA, and CIHEAM (Casas, Joseph; Solh, Mahmoud; and Hafez, Hala, eds.). The National Agricultural Research System of Eritrea. The National Agricultural Research Systems in the West Asia and North Africa Region. ICARDA, Aleppo, Syria, December 1999.

31. Fisheries Proclamation, Part III, Art. 11

32. Morgan, G. (2004). Country review: Eritrea. In FAO Fishery and Aquaculture Economics and Policy Division. Review of the state of world marine capture fisheries management: Indian Ocean. Retrieved from http://www.fao.org/3/a-a0477e/a0477e0j.htm 


\section{FISHING AUTHORITY UNDER THE MINISTRY: TANZANIA}

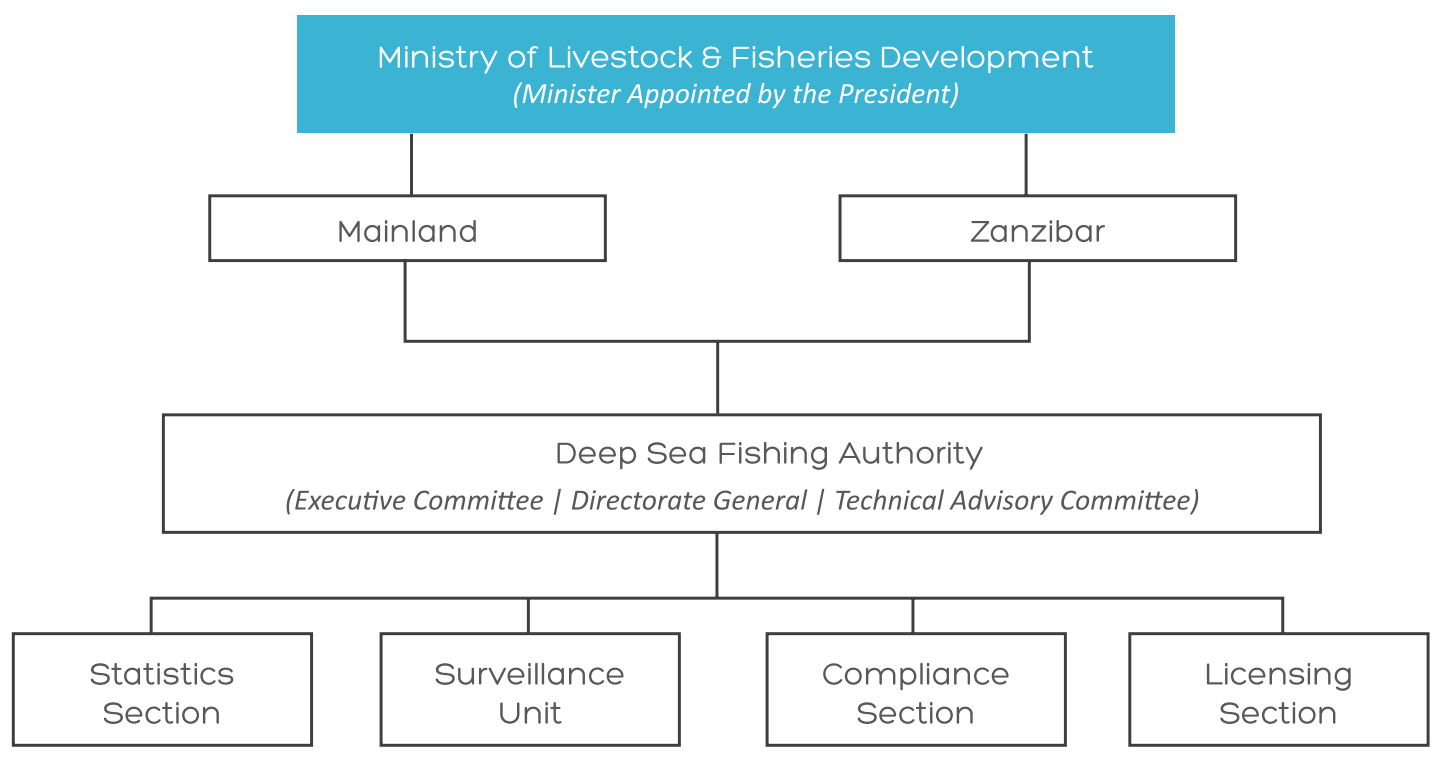

Tanzania manages both its inland and marine fisheries through the Ministry of Livestock and Fisheries Development. A branch of the Ministry, The Deep Sea Fishing Authority (DSFA), manages Tanzania's marine resources between the boundary of its territorial sea, 12 nautical miles from the coast, and its EEZ, 200 nautical miles from the coast. ${ }^{1}$ The DSFA was created through the Deep Sea Fishing Authority Act of $2009^{2}$ (see Appendix 3 for the full legislation text).

The Ministers of Livestock and Fisheries Development from mainland Tanzania and Zanzibar have the ultimate authority over the DSFA and are responsible for nominating candidates for the positions of Director General and Deputy Director General. $^{3}$ The candidates are submitted to the President of Tanzania for approval; it is required that one come from mainland Tanzania and the other from Zanzibar to equally represent both regions' interests. Together with the department directors, they form the Directorate General.

The DSFA consists of two other main bodies besides the Directorate General: the Executive Committee and the Technical Advisory Committee. The Executive Committee provides another connection between the Ministry and the DSFA. Their main purpose is to approve the budget and future objectives of the DSFA. Many of the decisions of the Director General must be approved by the Executive Committee. The Technical Advisory Committee consists of the fisheries Directors from mainland Tanzania and Zanzibar as well as other experts and stakeholders including scientific researchers, economists, lawyers, and members of fishing industry. The Technical Advisory Committee may make policy proposals and provide fisheries advice. ${ }^{4}$

\section{Creation of Fisheries Regulations and Management Measures}

The DSFA governs Tanzania's marine fisheries resources under principles of sustainability and creates fisheries policies based on stock assessments. ${ }^{5}$ If necessary, the Director General may also place restrictions on fishing gear or fishing methods and put policies in place to restore fish stocks. ${ }^{6}, 7$

\section{Licensing}

The DSFA licenses domestic and foreign fishing vessels and individuals conducting scientific research. ${ }^{8}$ The licenses are issued by the Director General. A vessel must first go through a licensing application process, after which the DSFA inspects the vessel, issues an approval letter, and the vessel owner pays a license fee. ${ }^{9}$ Both foreign and domestic licenses generate 
revenue. Half of this revenue goes to the federal government and the other half goes back into the operational budget of the DSFA. The DSFA established a licensing department to oversee each step of the licensing process and to publish a full list of licensed vessels on the DSFA website. ${ }^{10}$

\section{Catch and Effort Data Collection and Analysis, Observer Program}

The Statistics Section of the DSFA is responsible for collecting, processing, and analyzing catch and effort data. This is a requirement of both the Authority and the regional fisheries management organizations (RFMOs) to which Tanzania belongs. Specifically, the Statistics Section is required to collect catch data, licensing data (such as vessel and fishing information), perform analyses, produce reports, and disseminate information. ${ }^{11}$

The Director General appoints a group of observers. Observers are trained and equipped by the DSFA prior to boarding a fishing vessel. They are responsible for collecting information on harvesting, handling, and processing of catch while on board a vessel. Furthermore, observers collect biological data and take samples or photos of catch. ${ }^{12}$ To supplement observer data, captains of licensed vessels are required to keep logbooks containing fish catch information. The captain must surrender their logbook to anyone authorized by the Director General. ${ }^{13}$

\section{Monitoring, Control, Surveillance, Enforcement}

The largest responsibility of the DSFA is MCS. The Deep Sea Fishing Authority Act of 2009 provides a thorough mandate of MCS responsibilities. The DSFA has a vessel monitoring operation center with current Vessel Monitoring System (VMS) technology approved by the Director General. ${ }^{14}$

There are three main units in charge of executing the DSFA's MCS responsibilities:

1) A Surveillance Unit composed of a group of enforcement officers established by the Director General and the Executive Committee. ${ }^{15}$

2) A group of inspectors who are allowed to stop and board fishing vessels to inspect the vessel itself, documentation, gear, crew, and catch. In the case of a suspected offense, inspectors may seize a vessel, its gear, documents, and other relevant items, or order the captain to dock the vessel. ${ }^{16}$

3) Authorized Officers composed of officers from the DSFA as well as enforcement officials from other government groups such the Defense Force, Police Force, and fisheries officers of the Ministry.

The Compliance Section of the DSFA also covers MCS duties. It is responsible for overseeing licensed vessels, ensuring compliance with DSFA regulations, conducting pre-license inspections, executing air and sea patrols, and overseeing VMS tracking. ${ }^{17}$

\section{Fisheries Crime Prosecution}

Punishment for violation of the DSFA regulations is severe. Violators are fined at least one billion TZS (approximately 450,000 USD), face at least 20 years imprisonment, and must forfeit their vessel or relevant gear. ${ }^{18}$ Relevant cases are submitted to law enforcement and the attorney general for prosecution.

\section{Regional Fishery Management Organization Participation}

The DSFA is authorized to enter into fishing agreements and contracts with other governments or international organizations. ${ }^{19}$ It complies with the Indian Ocean Tuna Commission (IOTC). ${ }^{20}$

\section{Research Science}

Though much of the fisheries research in Tanzania focuses on the Lake Victoria region and inland fisheries, the Tanzania Fisheries Research Institute (TAFIRI) also conducts research on marine resources. TAFIRI is a separate institute under the 
Ministry, but it forms part of the Technical Committee of the DSFA. All scientific recommendations made by the DSFA come directly from TAFIRI. ${ }^{21}$

\section{Considerations and Implications for This System}

By granting the DSFA jurisdiction beyond 12 nautical miles but within Tanzania's EEZ, Tanzania created a clear geographical distinction between the DSFA and the Ministry. This system minimizes overlap of jurisdictions and responsibilities between the two groups. However, the DSFA benefits from remaining under the auspices of the Ministry and maintaining their connection through the Executive Committee. The system also allows for the full incorporation of the islands of Zanzibar which is crucial to maintaining the Authority's effectiveness.

The incorporation of the Ministry and Zanzibar into the DSFA may have drawbacks in terms of coordination and cooperation. The DSFA must answer to the Ministry, which removes some of their autonomy. The connection with the Ministry may also blur responsibilities between the Ministry and the DSFA, or create coordination issues. This could pose a problem for revenue sharing decision-making, as the Ministry may have different interests when deciding where revenue should be used. The incorporation of Zanzibar may also provide coordination issues, as it is a nearly autonomous region and has different laws and procedures from mainland Tanzania. ${ }^{22}$

The geographic distinction allows the DSFA to focus on MCS while leaving the management of artisanal and local fishing to the Ministry. A strong MCS system is a crucial component to controlling fishing in Tanzania's offshore waters. The DSFA's founding legislation thoroughly documents the different groups and procedures required for MCS. This detailed planning and prioritization of MCS is imperative to protect Tanzanian waters and fight IUU fishing.

In most cases, such ambitious provisions for MCS, enforcement, and licensing require a large staff. According to a World Bank workshop report, this was a challenge in Tanzania as the DSFA only consisted of eight employees in 2011. While DSFA was able to meet their internally established goal for observations of vessel catch and effort, they did not have the capacity to meet their licensing revenue expectations in 2011. ${ }^{23}$ Though the DSFA has been able to function in subsequent years without adding personnel, a country with a larger area to police would need more people to thoroughly cover its jurisdiction.

Finally, the penalties for regulatory violations are severe compared to other countries. The harsh punishments imposed by the DSFA are not necessarily appropriate for minor fisheries crimes. Thus, these crimes may go unaddressed and unpunished. ${ }^{24}$ It would be beneficial to create different tiers of punishment to fit fisheries crimes of varying degrees of severity. 


\section{Notes (Tanzania)}

1. NFDS, POSEIDON, COFREPECHE and MRAG, 2014. Ex ante evaluation of a possible future fisheries partnership agreement and protocol between the European Union and the United Republic of Tanzania (Framework contract MARE/2011/01 - Lot 3, specific contract 7). Brussels, 108 p.14. Retrieved from http://ec.europa.eu/fisheries/documentation/studies/tanzania/doc/ex-ante-evaluation-tanzania en.pdf

2. The Deep Sea Fishing Authority Act (Cap. No. 388). (6 March 2009). Government Notice No. 48. Retrieved from http://www.tanzania.go.tz/ egov uploads/documents/DSFA REGULATIONS 2009 sw.pdf

3. The United Republic of Tanzania. Deep Sea Fishing Authority Act, No. 1 of 1998. Part III.6 Retrieved from http://www.tanzania.go.tz/egov uploads/documents/DSFA 1998 sw.pdf

4. NFDS, POSEIDON, COFREPECHE and MRAG, 2014.

5. Deep Sea Fishing Authority Act, 2009, Part III.20

6. Deep Sea Fishing Authority Act,2009, Part III.22

7. Deep Sea Fishing Authority Act, 2009, Part III.21

8. Corsi, Anna. 2012. Aide Memoire MACEMP Feb 2012 for clearance.docx. Washington, D.C. : World Bank Group. Retrieved from http://documents.worldbank.org/curated/en/2012/06/16406478/aide-memoire-macemp-feb-2012-clearancedocx

9. Deep Sea Fishing Authority. License Application Process. Retrieved from http://www.dsfatz.org/our-services/license-application-process.html

10. Deep Sea Fishing Authority. Licensing Section. Retrieved from http://www.dsfatz.org/our-services/licensing-section.html

11. Deep Sea Fishing Authority. Statistics Section. Retrieved from http://www.dsfatz.org/our-services/statistics-section.html

12. Deep Sea Fishing Authority Act, 2009, Part V.34

13. Deep Sea Fishing Authority Act, 2009, Part V.40

14. Deep Sea Fishing Authority Act, 2009: Part V.29

15. Deep Sea Fishing Authority Act, 2009, Part V.31,32

16. Deep Sea Fishing Authority Act, 2009, Part V.33

17. Deep Sea Fishing Authority. Compliance Section. Retrieved from http://www.dsfatz.org/our-services/compliance-section.html

18. NFDS, POSEIDON, COFREPECHE and MRAG, 2014.21

19. Deep Sea Fishing Authority. Director's Statement. Retrieved from: http://www.dsfatz.org/about-us/directors-statement.html

20. Deep Sea Fishing Authority. Compliance Section.

21. Tanzania Fisheries Research Institute. Retrieved from http://tafiri.weebly.com/

22. NFDS, POSEIDON, COFREPECHE and MRAG, 2014.20

23. Corsi, Anna. 2

24. NFDS, POSEIDON, COFREPECHE and MRAG, 2014.21 
MANY GOVERNMENT DEPARTMENTS: KENYA

KENYA

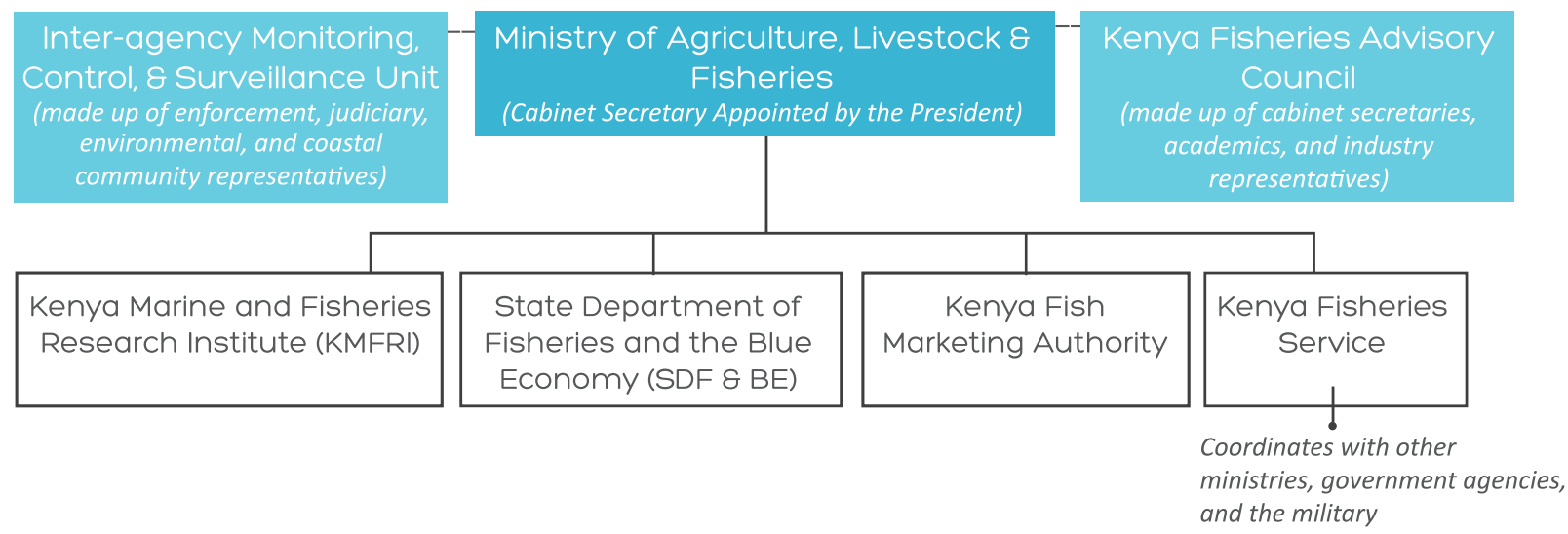

Kenya's marine fisheries management structure is relatively new and is currently evolving. Until 2013, marine fisheries were managed by the Ministry of Fisheries Development that also handled the much larger inland fisheries sector. With the election of a new President in 2013 and his issuance of Executive Order No. $1^{1}$ (see Appendix 4a for the full executive order text), the entire structure of fisheries management, including names of ministries and departments, changed drastically.

The marine sector is now managed under the Ministry of Agriculture, Livestock and Fisheries, but many government organizations and sub-sections of the Ministry are responsible for different areas of policy creation and implementation. The President appoints the head of the Ministry, the Cabinet Secretary. Fisheries management provisions were outlined in the Fisheries Act Chapter 378 passed by Parliament in 1991 and revised in 2012 (see Appendix 4b for the full legislation text) ${ }^{2}$ and further updated by the Fisheries Management and Development Act No. 35 (see Appendix 4c for the full legislation text) passed in September 2016.

Under the Ministry, the President established the State Department of Fisheries and the Blue Economy (SDF \& BE) to separate fisheries management from livestock and agriculture. The SDF \& BE is the executive arm mandated to oversee the exploration, exploitation, utilization, management, and development of the country's fisheries. Within the SDF \& BE there are further divisions such that marine and coastal fisheries are managed separately from inland fisheries, aquaculture, and quality assurance. The Principal Secretary of the SDF \& BE is appointed by the President with parliamentary approval.

The Fisheries Management and Development Act of 2016 details fisheries laws with an emphasis on conservation and management based on ecological sustainability and improving fishing community livelihoods by maximizing the economic value of the fisheries. It also creates new government agencies including the Kenya Fisheries Advisory Council, Kenya Fisheries Service, Kenya Fish Marketing Authority, and the Inter-Agency Monitoring, Control and Surveillance Unit. Further relevant details about these groups are within the sections below.

The Kenya Fisheries Advisory Council has a similar structure and function to that of Eritrea's (see Ministry with an Advisory Council: Eritrea, p. 9). The council consists of the Cabinet Secretaries responsible for fisheries, interior, transportation and infrastructure, treasury, and foreign affairs and international trade. It also has representatives from a university or research institution, consumer federation, the Council of Governors, and the fishing industry. The Cabinet Secretary is in the process of appointing each representative as of the time of this writing. The council is tasked with providing advice and reviewing matters related to fisheries including policies, management plans, intergovernmental agreements, and allocation of fisheries resources. ${ }^{4}$

Alongside the Ministry and fisheries agencies, there are many other agencies that are involved in aspects of fisheries management, from other ministries and government departments to the military. Any institution that has jurisdiction 
over a matter that could be fisheries-related has some influence in that area. For example, because fish live in water, the Ministry of Water and Irrigation and the Ministry of Environment and Natural Resources are involved in fish habitat protection. When enforcement is necessary on the water, the Kenya Fisheries Service can request patrols from the Kenya Navy. There is coordination and communication among the involved groups to effectively manage issues that may span multiple agencies.

\section{Creation of Fisheries Regulations and Management Measures}

The Ministry of Agriculture, Livestock and Fisheries creates fisheries policies, and the SDF \& BE is the executive arm in charge of implementation. ${ }^{6}$ The Fisheries Act contains the broad duties of the Ministry for managing fisheries. The details of fisheries management are discussed in regulations that are published in the Kenya Gazette after approval by the Cabinet Secretary.

According to the Fisheries Management and Development Act of 2016, the Kenya Fisheries Service can make any regulations regarding many areas of fisheries management, including: 1) management and conservation plans, 2) access to and allocation of fisheries resources for domestic or international use, 3) collecting and analyzing data on fishing activities, 4) marketing of fish and fish products including import and export restrictions, 5) raising revenues from fishing and facilitating investment in commercial fisheries, and 6) coordinating monitoring, control, and surveillance. The Cabinet Secretary approves regulations created by the Kenya Fisheries Service.

Kenya's small-scale artisanal fisheries have been managed by a system of Beach Management Units (BMUs) since 2006, after decades of high exploitation decimated fish populations. BMUs are a system of co-management in which the fishers have a say in the regulation of the fisheries important to their communities and livelihoods. Each county has a network of BMUs with fisheries officers that report to the district and the Director-General of the Kenya Fisheries Service. Additionally, co-management is encouraged between the BMUs and county governments to create bylaws for the fishers to sustainably manage the resources. ${ }^{9}$ Local management of small-scale fisheries has been successful in Kenya, resulting in an increase in fish biomass and diversity. ${ }^{10}$

Licensing

All fishing vessels must be licensed in order to fish in Kenyan waters. The Director-General of the Kenya Fisheries Service is responsible for vessel registrations and for establishing and maintaining a database of licensed vessels. ${ }^{11}$ Local vessels are prioritized and foreign vessels are allotted licenses if it is determined that there are excess resources after local exploitation levels are considered. ${ }^{12}$ Detailed requirements to obtain a license are described in the Fisheries Management and Development Act of 2016. ${ }^{13}$

Catch and Effort Data Collection and Analysis, Observer Program

Most of the coastal catch and effort data collected are from the small-scale sector through the BMUs. Kenya Marine and Fisheries Resources Institute (KMFRI), the research science branch of the Ministry (see "Research Science" section below) conducts stock assessments and looks at fish population dynamics to inform management. ${ }^{14}$

The Kenya Fisheries Service collaborates with KMFRI to place observers on commercial fishing vessels. The Kenya Fisheries Service collects and maintains the data from these vessels and uses it to make management decisions. ${ }^{15}$, $^{16}$

Monitoring, Control, Surveillance, Enforcement

MCS capacity in Kenya is low. The Kenya Port Authority had a vessel monitoring system (VMS), but as of February 2016, it is not functional. ${ }^{17}$ The Kenya Navy is tasked with conducting patrols for suspicious fishing vessels. It does not conduct regular patrols, but will do so at the request of the Kenya Fisheries Service. ${ }^{18}$ The Marine Police, a branch of the Kenya 
Police Service, is mandated to protect fishing vessels and ports, but its jurisdiction is limited to within 12 nautical miles of shore. ${ }^{19}$ The new Fisheries Management and Development Act of 2016 created an inter-agency MCS unit composed of members of a variety of agencies under the national government. This will allow the variety of agencies involved in MCS and enforcement to cooperate and effectively track and catch illicit fishing vessels. ${ }^{20}$

The Fisheries Management and Development Act of 2016 defines authorized officers as any official under the Kenya Fisheries Service, including inspectors and naval or other armed forces officers. ${ }^{21}$ The powers of officers include stopping, boarding, and inspecting a vessel, vehicle, or premises suspected of being used for fishing offences. The officers can confiscate catch, gear, documents, and the vessel or vehicle. They can also arrest any person suspected of fisheries crimes. ${ }^{22}$ As of 2014 , two officers were trained for port inspections. ${ }^{23}$ However, Kenya is set to open the Fisheries Crimes Law Enforcement Academy in Nairobi in order to train more enforcement officers and crack down on IUU fishing in Kenyan waters. ${ }^{24}$

\section{Fisheries Crime Prosecution}

The system of prosecution in Kenya is unique among the other countries in the region. The Fisheries Act gives the Attorney General the power to allow an authorized fisheries officer to conduct prosecutions for offenses under the Fisheries Management and Development Act of 2016. In that capacity, the authorized officer has the same powers as a public prosecutor. ${ }^{25}$

The penalty for a fishing violation could be time in jail, a fine, or both. The penalties vary with the severity of the crime committed and are determined during administrative proceedings. ${ }^{26}$ Fisheries crimes are brought to court, and crimes involving a foreign vessel are brought to the High Court. Further details about penalties for convictions of fisheries crimes are outlined in the Fisheries Management and Development Act of 2016. They include forfeiture of property and monetary penalties. ${ }^{27}$

\section{Regional Fishery Management Organization Participation}

Kenya is a member (Contracting Party) of the Indian Ocean Tuna Commission (IOTC) and the South West Indian Ocean Fisheries Commission (SWIOFC). ${ }^{28}$

\section{Research Science}

The Kenya Marine and Fisheries Resources Institute (KMFRI) is a semi-autonomous research institute under the Ministry. In addition to stock assessments, KMFRI conducts fishery-independent research on commercially and ecologically important fish species. Their goal is to provide information to inform sustainable exploitation, management, and conservation of Kenya's aquatic resources, both in marine and freshwater environments. They are involved in projects to reduce postharvest mortality of captured fish, develop new aquaculture methods, survey the chemical and physical processes in the marine environment, and survey socioeconomics in coastal fishing communities. ${ }^{29}$

\section{Considerations and Implications for This System}

Kenya is still modifying its coastal fisheries management after many years of focusing on the inland fisheries. One benefit of having many organizations with some level of involvement in coastal fisheries is that there are more human resources to draw upon. It is useful to be able to deploy agents from other organizations when the Ministry needs additional support. Splitting the areas of fisheries governance among different organizations allows each group to specialize. When a multifaceted issue arises, it is useful to be able to consult multiple perspectives from a variety of government organizations to find creative solutions. Effective communication and coordination among the groups is crucial to realizing this benefit and will be aided by the Kenya Fisheries Advisory Council once it is created and implemented. 
However, there are potential drawbacks to the system in Kenya.

1) The fisheries laws in Kenya have changed dramatically over the past few years. The number of recent changes could lead to confusion among Kenyan fishers and foreign vessels about which laws and systems have changed and the legality of their current activities. It could also cause confusion among enforcement officers and the international community if they are not properly trained in the procedures under the new law.

2) A system that involves many autonomous organizations is complicated and it is difficult to know who handles certain tasks.

3) Having many organizations working on similar issues creates the potential for mission overlap, or the risk of items falling through the cracks, especially if there is not adequate communication among the groups.

4) With many people in positions of power, but managing the same issue, any process that spans multiple government agencies could be bogged down in bureaucracy and micromanagement by the Cabinet and Principle Secretaries.

5) The Kenyan system places a comparatively large amount of power in the hands of the Director-General of the Kenya Fisheries service. The D-G is accountable to the Board of Directors and the Cabinet secretary under this system, but is also solely responsible for collecting license fees. Institutionalized accountability and oversight are therefore imperative. 


\section{Notes (Kenya)}

1. Executive Order No. 1: Structure of the National Executive.( 2013). The Kenya Gazette, Vol. CXV-No. 61. Retrieved from http://kenyalaw.org/ kenya gazette/gazette/volume/NzQ4/Vol.\%20CXV-No.\%2061

2. Fisheries Act (Cap. 378). (31 December 2012). Laws of Kenya. Retrieved from http://faolex.fao.org/cgi-bin/faolex.exe?rec id=002186\&database=faolex\&search type=link\&table=result\&lang=eng\&format name=@ERALL

3. Fisheries Management and Development Act No. 35 of 2016. (3 September 2016). Kenya Gazette Supplement, No. 156. (Acts No. 35). Retrieved from http://kenyalaw.org/kl/fileadmin/pdfdownloads/Acts/FisheriesManagementandDevelopmentAct No35of2016.pdf

4. Fisheries Management and Development Act, Part II Section 6

5. POSEIDON, MRAG, COFREPECHE and NFDS. (2014). Ex ante evaluation of a possible future fisheries partnership agreement and protocol between the European Union and Kenya (Framework contract MARE/2011/01 - Lot 3, specific contract 7). Brussels, 91 p. Retrieved from http:// ec.europa.eu/fisheries/documentation/studies/tanzania/doc/ex-ante-evaluation-tanzania en.pdf

6. POSEIDON et al., Ex ante evaluation

7. Ibid.

8. Fisheries Management and Development Act, Part II Section 9

9. Fisheries Management and Development Act, Part V

10. Le Manach, F., Abunge, C.A., McClanahan, T.R., Pauly, D. (2015). Tentative reconstruction of Kenya's marine fisheries catch, 1950-2010. Pp. 37-51 In Le Manach, F. and Pauly, D. (eds.). Fisheries catch reconstructions in the Western Indian Ocean, 1950-2010. Fisheries Centre Research Reports 23(2). Fisheries Centre, University of British Columbia [ISSN 1198-6727].

11. Fisheries Management and Development Act, Part X

12. Fisheries Act, Part IV

13. Part $X$ Section 88

14. Kenya Marine and Fisheries Research Institute. Marine and Coastal Systems website. Retrieved from http://www.kmfri.co.ke/index.php/divisions/marine-and-coastal-systems

15. Fisheries Management and Development Act, Part IX

16. AU-IBAR. (2016). Status of Fisheries Observer Programmes in Eastern Africa and a framework for Sea-based Regional Fisheries Observer Programme. AU-IBAR Reports. Retrieved from http://www.au-ibar.org/component/idownloads/finish/5-gi/2837-status-of-fisheries-observerprogrammes-in-eastern-africa-and-a-framework-for-a-sea-based-regional-fisheries-observer-programme

17. Oketch, W. (8 February 2016). KP revenues, security at risk as Sh300m tracking system collapses. Standard Digital. Retrieved from: http://www.standardmedia.co.ke/article/2000190886/kpa-revenues-security-at-risk-as-sh300m-tracking-system-collapses?articleID=2000190886\&story title=kpa-revenues-security-at-risk-as-sh300m-tracking-system-collapses\&pageNo=2

18. POSEIDON et al., Ex ante evaluation

19. Ibid.

20. Fisheries Management and Development Act, Part III Section 20

21. Fisheries Management and Development Act, Part III Sections 18, 19

22. Fisheries Management and Development Act, Part XIII

23. POSEIDON et al., Ex ante evaluation

24. Omulo, C. (18 November 2016). Kenya Govt to launch academy to fight fisheries crime. Daily Nation. Retrieved from http://www.hiiraan.com/ news $4 / 2016 /$ Nov/128804/kenya govt to launch academy to fight fisheries crime.aspx

25. Fisheries Management and Development Act, Part XVI

26. Ibid.

27. Fisheries Management and Development Act, Part XVII

28. Indian Ocean Tuna Commission. Structure of the Commission. Retrieved from http://www.iotc.org/about-iotc/structure-commission

29. Kenya Marine and Fisheries Research Institute. Mombasa Centre website. Retrieved from http://www.kmfri.co.ke/index.php/centres/mombasa-center 


\section{SEMI-AUTONOMOUS FISHING AUTHORITY: SEYCHELLES}

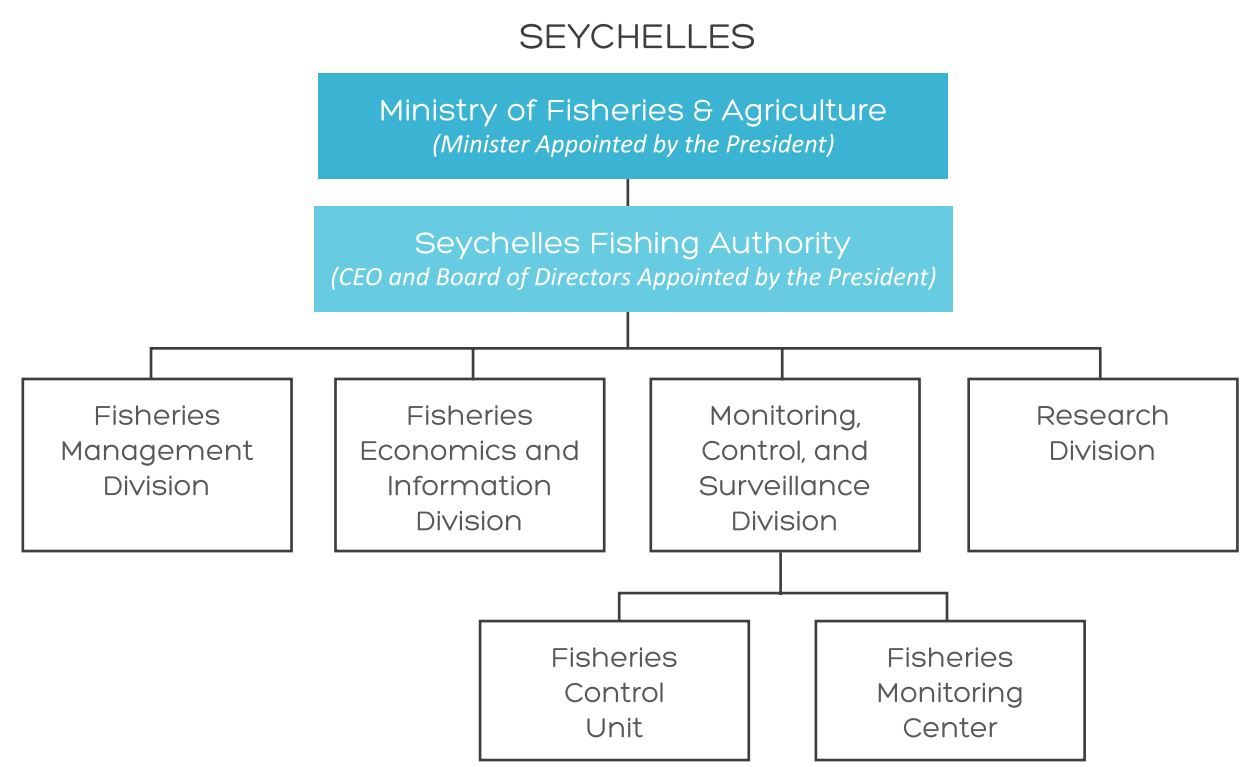

The Republic of the Seychelles has a unique model among eastern African countries. The majority of fisheries management responsibilities reside within the Seychelles Fishing Authority (SFA), a government body under the Ministry for Fisheries and Agriculture. Though still under the Ministry like the Tanzania Deep Sea Fishing Authority, the SFA maintains the autonomy to manage fisheries with minimal interference by the federal government.

The SFA was established in 1984 with the passage of the Seychelles Fishing Authority (Establishment) Act, ${ }^{1}$ which was updated in 2012 (see Appendix 5a for the full text of the act). ${ }^{2}$ The SFA is a corporate body that operates similarly to a business. The duties of the SFA and fishing regulations for the country are outlined in the Fisheries Act, originally passed in $1986^{3}$ and updated in 2014 (see Appendix 5b for the full text of the act). ${ }^{4}$

The SFA is led by a Board of Directors including a Chairman, all appointed by the President. Under the Board of Directors, the SFA is divided into four implementation divisions: 1) Fisheries Management, 2) Fisheries Economics and Information, 3) Monitoring, Control and Surveillance, and 4) Research. ${ }^{5}$ The President also appoints a Chief Executive Officer (CEO) to the SFA. The CEO manages the daily affairs of the SFA and is part of the Special Advisors to the President, thereby providing a link between the President's office and the SFA. The CEO attends meetings of the Board of Directors, but has no voting rights. $^{6}$

The SFA is connected to the federal government through the President-appointed Minister of Fisheries and Agriculture. The Minister's most important task is to establish fishing agreements with other countries, intergovernmental organizations, and foreign vessel owner associations. Without an agreement, a foreign vessel cannot be licensed to fish in Seychelles waters. This allows the Minister and SFA to control the allocation of fishing rights and ensure fisheries exploitation is held at sustainable levels. ${ }^{7}$ To expand this assurance to the entire region, the Minister forms agreements with states or regional organizations to harmonize surveillance and enforcement measures. ${ }^{8}$

The Minister also establishes the outlines of fisheries policies and gives final approval for management plans and scientific proposals. ${ }^{9}$ Those policies and decisions are informed by the work of the SFA, which develops the specifics of the management plans and handles all other fishing related activities. 
Creation of Fisheries Management Measures and Regulations

The Fisheries Act gives the SFA complete authority to manage the marine resources of the Seychelles. ${ }^{10}$ The Fisheries Management Department of the SFA sets a management plan that takes into account the current state of the ecosystem and socioeconomic climate, while promoting sustainability and conservation of important marine habitats. It sets harvest controls based on the recommendations of the Indian Ocean Tuna Commission (IOTC). It also creates the licensing requirements for industrial fisheries based on consultation with scientists, local fishers, industrial fishers, and other Indian Ocean States. Management plans are approved by the Minister and made publicly available. ${ }^{11}$

The SFA develops management plans for their domestic fisheries. The artisanal fishing sector in the Seychelles is small relative to the industrial sector. As such, there are few regulations for local fishers. Some restrictions are placed on 1) catch of vulnerable species such as turtles and sharks, 2) gear including bottom trawls, spear-fishing, and nets for shark fishing, 3) fishing season for sea cucumbers and lobsters, and 4) fishing area. However, there are no limits on catch levels for artisanal fishers. ${ }^{12}$

Licensing

The fishing vessel licensing requirements in the Seychelles are extensive and thoroughly outlined in the Fisheries Act. ${ }^{13}$ All vessels must be licensed to fish in Seychelles waters, with the majority of requirements aimed at the foreign vessels, which are responsible for nearly all of the catch in Seychelles waters. In addition to completing an application and paying a fee, a vessel applying for a license and its owner must not have engaged in or supported IUU fishing activities in Seychelles waters or elsewhere. The SFA coordinates with regional fisheries management organizations (RFMOs), other licensing authorities, and international organizations to confirm the legitimacy of vessels applying for licenses. Additionally, foreign vessels must be represented in an agreement between their state and the Minister of Fisheries and Agriculture of the Seychelles. ${ }^{14}$ License fees and limits on the number of fishing vessels allowed are detailed in the agreement. The SFA is responsible for enforcing the terms of that agreement. ${ }^{15}$

All licensed fishing vessels are subject to regulations imposed by the SFA. These include restrictions on gear, fishing area, closed periods, target species, and bycatch. There are requirements for the vessel itself including proper communication, vessel monitoring, and position fixing equipment. There are also mandatory catch reporting requirements. ${ }^{16}$ Licensed vessels that fish in Seychelles waters are encouraged to land their catch in Port Victoria, Seychelles, and purchase their supplies there. This regulation was created in 2010 to bolster the economy in Victoria. ${ }^{17}$ The revenue this earns for fishingrelated industries such as tuna processing and canning has allowed the sector to grow and has increased their capacity. ${ }^{18}$

Licenses are processed by the Fisheries Control Unit, a subsection of the Monitoring, Control, and Surveillance Section of the SFA. The Fisheries Control Unit keeps detailed records of licensed vessel information and makes these records publicly available on their website and in local newspapers. ${ }^{19}$ Also, as a member of the IOTC, the SFA provides a list of vessels authorized to fish for highly migratory species, which the IOTC publishes on their website. License revenue, in addition to federal funds, is used by the SFA to maintain its operations. Aid or grants received from other countries or international organizations are invested into fishing-related infrastructure, businesses, or projects. ${ }^{20}$

\section{Catch and Effort Data Collection and Analysis, Observer Program}

The Fisheries Economics and Information Section of the SFA collects catch and effort data from licensed fishing vessel logbooks and publishes their analyses for distribution to government, non-government, international, and industry organizations. ${ }^{21}$ Reporting of these data is mandatory and must include composition, amount, and location of catch on a daily basis. Data are collected in port from vessels landing their catch in the Seychelles. Vessels that do not land in the Seychelles must report the quantity of fish on board by species and vessel position during fishing to the SFA upon entering or leaving Seychelles waters. ${ }^{22}$ 
In order to comply with IOTC resolutions, the SFA maintains an observer program to monitor the licensed vessels fishing for highly migratory species such as tuna and billfish. ${ }^{23}$ They collect biological data on catch within and outside the Seychelles EEZ and submit their reports to the IOTC. The SFA is working to expand their observer capacity to increase coverage of the fishing fleet. ${ }^{24}$

\section{Monitoring, Control, Surveillance, Enforcement}

The Monitoring, Control, and Surveillance (MCS) Section of the SFA ensures fishing vessel compliance with national, regional, and international laws and regulations within the Seychelles' exclusive EEZ. ${ }^{25}$ Vessels registered to the Seychelles but fishing outside its waters are also monitored by the SFA to ensure compliance with international regulations. The Fisheries Monitoring Center (FMC), a subsection of the MCS Section, maintains a satellite based vessel monitoring system (VMS) to track licensed fishing vessels. ${ }^{26}$

Additionally, the Seychelles is part of the Regional Fisheries Surveillance Project. It is an MCS hub for other southwest Indian Ocean countries to help patrol and monitor their waters. Physical patrols of Seychelles waters are conducted by the SFA in coordination with the Seychelles Coast Guard. ${ }^{27}$

The Fisheries Act outlines in great detail the enforcement measures pursuant to international conservation and management guidelines. Fishery officers are authorized by the Minister and include public service, defense, or drug enforcement officers deemed necessary to assist in enforcement matters. They act under the jurisdiction of the SFA. The Fisheries Act clearly states the legal abilities of fisheries officers both on land and on the water. It also describes the proper procedures for officers to follow regarding seizure and detention of vessels or items suspected in illegal fishing. ${ }^{28}$ These officers are trained in the fisheries law, inspection procedures, and operation of VMS. ${ }^{29}$

Officers may stop, board, search, and inspect any vessel in Seychelles waters as well as vessels on the high seas that are either flagged to the Seychelles or signatories of an international agreement to which the Seychelles is a party. When searching a vessel, an officer may inspect and confiscate anything related to an infraction of the Fisheries Act including: 1) the vessel itself, 2) documents such as licenses, logbooks, and other fishing records, 3) records from the crew, 4) electronic devices used for communication or tracking of the vessel, 5) fish catch or fish products, 6) fishing gear, and 7) any other item that could be used as evidence of fishing crimes. Fishery officers can also search any person, vehicle, or facility on land that is associated with suspect fishing businesses. The broad jurisdiction of fishery officers allows them to collect all the evidence necessary to effectively prosecute fisheries crimes. ${ }^{30}$

\section{Fisheries Crime Prosecution}

While evidence of illegal fishing is collected by the fishery officers under SFA jurisdiction, prosecutions of fisheries crimes are handled by the Attorney General of the Seychelles. Once convicted, minimum fines for fishing crimes are conferred based on the Fisheries Act, ${ }^{31}$ which also outlines the reasons for cancellation or revocation of a fishing license. ${ }^{32}$

Regional Fishery Management Organization Participation

The Seychelles is an active member of the IOTC. ${ }^{33}$ They were also a leader in the South West Indian Ocean Fisheries Project (SWIOFP) in which they spearheaded regional collaboration on licensing conditions for highly migratory species. ${ }^{34}$ They also belonged to the Agulhas and Somali Current Large Marine Ecosystem (ASCLME). ${ }^{35}$ However, SWIOFP and ASCLME projects have ended.

\section{Research Science}

The Research Division of the SFA conducts fishery-independent scientific research and stock assessments for fish species with the highest commercial value. Their projects are aimed at developing appropriate management strategies and 
improving fishing techniques. They receive financial and research grants from regional and international organizations which help them maintain ongoing projects, a research vessel, and two laboratory facilities. ${ }^{36}$

\section{Considerations and Implications for This System}

There are many benefits to a semi-autonomous fishing authority. The system is structured to accommodate the needs of the fishing sector without being hindered by excessive government bureaucracy. Though the SFA is under the Ministry, it has the ability to manage the fisheries of the Seychelles based on the best scientific and regional knowledge available. Overall, the SFA is a strong model because its specific duties and budget are separate from those of the Ministry, so the two do not compete for funds or jurisdiction.

The Seychelles Fisheries Act is detailed and well organized. It incorporates many IOTC resolutions, ${ }^{37}$ making it easy to create compliant access agreements for tuna vessels that adhere to sustainability standards of the region.

Depending on the perspective, there are potential benefits or drawbacks resulting from fishing license revenue being handled solely by the SFA and not the central government. This system benefits the fishing sector in that all the revenue is invested into management and development of the fishing sector. This also means that the revenue is not used for other development or socio-economic programs within the country. In the case of the Seychelles, which is economically dependent on fishing and has a very small total population, this may not be a problem. In other countries with a variety of developing economic sectors, there could be objections to using all the fishing revenue for fishing-related projects when other sectors are also in need of investment and support. 


\section{Notes (Seychelles)}

1. Seychelles Fishing Authority (Establishment) Act, 1984 (Cap. 214). Official Gazette, 31 August 1984. Retrieved from http://faolex.fao.org/cgi-

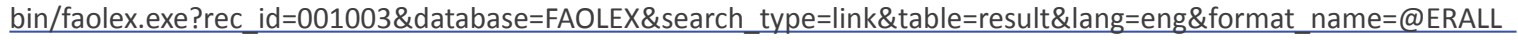

2. Seychelles Fishing Authority (Establishment) Act, consolidated to 30 June 2014. Retrieved from http://faolex.fao.org/cgi-bin/faolex.exe?rec

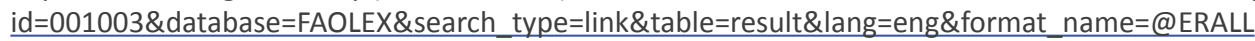

3. Fisheries Act 1986. Laws of the Seychelles. Retrieved from http://faolex.fao.org/docs/pdf/sey2117.pdf

4. Fisheries Act, 2014.(27 October 2014). Supplement to Official Gazette. Retrieved from http://faolex.fao.org/docs/pdf/sey143994.pdf

5. Seychelles Fishing Authority website. www.sfa.sc

6. Seychelles Fishing Authority (Establishment) Act 2014

7. Fisheries Act, 2014, Part II, Sub-part 2

8. Fisheries Act, 2014, Part V, Section 57

9. Martin, J.I. (2011). Fisheries in the Seychelles and Fisheries Agreements with the EU. Retrieved from http://www.europarl.europa.eu/RegData/etudes/note/join/2011/460060/IPOL-PECH NT(2011)460060 EN.pdf

10. Fisheries Act, 2014, Part II, Sub-part 2

11. Fisheries Act, 2014, Part II, Sub-part 1

12. NFDS, MRAG, COFREPECHE and POSEIDON. (2013). Ex post evaluation of the current Protocol to the Fisheries Partnership Agreement between the European Union and the Republic of Seychelles and ex ante evaluation including an analysis of the impacts of the future Protocol on sustainability (Framework contract MARE/2011/01 - Lot 3, specific contract 4). Brussels, 157 p.

13. Fisheries Act 2014 Part III

14. Fisheries Act 2014, Part II, Sub-Part 2

15. NFDS et al., Ex post evaluation

16. Fisheries Act 2014, Part II, Sub-Part 5

17. Fisheries Act Chapter 82 (Subsidiary Legislation). (2010). Laws of the Seychelles. Retrieved from http://www.seychellesmarinespatialplanning. com/wp-content/uploads/2014/06/Fisheries-Regs-Rev.-2010.pdf

18. NFDS et al., Ex post evaluation

19. Fisheries Act, 2014, Part II, Sub-part 1

20. NFDS et al., Ex post evaluation

21. Seychelles Fishing Authority. Fisheries Economic and Information website. http://www.sfa.sc/FisheriesEconomic.jsp

22. Fisheries Act 2014 Part III, Sub-Part 2

23. Assan, C., Lucas, J., Socrate, E., Holanda, S. (2015). Seychelles National Report to the Scientific Committee of the Indian Ocean Tuna Commission, 2015. IOTC-2015-SC18-NR23. Retrieved from http://www.iotc.org/documents/seychelles-\%E2\%80\%93-national-report-2015

24. Seychelles Fishing Authority. (2015). Annual Report 2013. Victoria, Mahé, Seychelles, 99pp. Retrieved from http://www.sfa.sc/publication.jsp

25. Seychelles Fishing Authority website. www.sfa.sc

26. Bergh, P.E. (2012). Comprehensive Review of MCS Capacity in the ESA-IO Region. Retrieved from http://www.fao.org/3/a-az384e.pdf

27. Seychelles Fishing Authority website. www.sfa.sc

28. Fisheries Act 2014, Part V

29. Bergh, Comprehensive Review

30. Fisheries Act 2014, Part V, Sub-Part 1

31. Fisheries Act 2014, Part VI

32. Fisheries Act 2014, Part III, Sub-Part 8

33. Indian Ocean Tuna Commission. Structure of the Commission. Retrieved from http://www.iotc.org/about-iotc/structure-commission

34. Seychelles Fishing Authority, Annual Report 2013

35. NFDS et al., Ex post evaluation

36. Seychelles Fishing Authority. Research website. http://www.sfa.sc/Research.jsp

37. NFDS et al., Ex post evaluation 


\section{APPENDICES for \\ AN EXPLORATION OF FEDERAL FISHERIES MANAGEMENT AGENCIES IN EASTERN AFRICA}

APPENDIX 1A: Full text of the Decreto Pesidencial n. ${ }^{\circ}$ 17/2015 from Mozambique. Published March 25, 2015, in the Boletim da República, I Série, Supplement, No. 24. (in Portuguese)

APPENDIX 1B: Full text of the Lei n. 22/2013 from Mozambique. Published November 1, 2013 in Boletim da República No. 88. (in Portuguese)

APPENDIX 2. Full text of the Fisheries Proclamation (No. 104/1998) from Eritrea. Published May 25, 1998, in the Gazette of Eritrean Laws, Vol. 8, No. 4.

APPENDIX 3. Full text of The Deep Sea Fishing Authority Act (Cap. No. 388) from Tanzania. Published March 6, March 2009 in Government Notice No. 48.

APPENDIX 4A. Full text of Executive Order No. 1: Structure of the National Executive of 2013. Published April 18, 2013 in The Kenya Gazette, Vol. CXV-No. 61.

APPENDIX 4B. Full text of the Fisheries Act (Cap. 378) from Kenya. Published December 31, 2012 in Laws of Kenya.

APPENDIX 4C. Fisheries Management and Development Act No. 35 of 2016

APPENDIX 5A. Full text of the Seychelles Fishing Authority (Establishment) Act, consolidated to 30 June 2014. Published in the Official Gazette.

APPENDIX 5B. Full text of the Fisheries Act, 2014 from the Seychelles. Published October 27, 2014 in the Supplement to Official Gazette. 


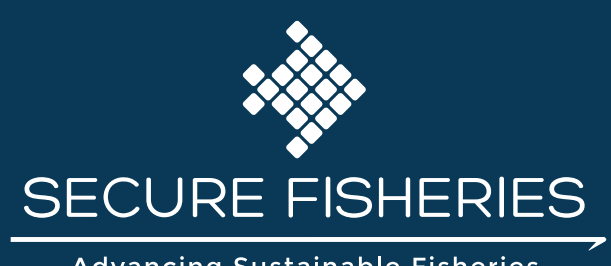

Advancing Sustainable Fisheries

Secure Fisheries is a program of the One Earth Future Foundation

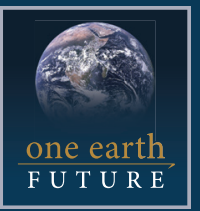

Peace Through Governance

oneearthfuture.org 